Int. J. Odontostomat., 8(2):165-169, 2014.

\title{
Epidermoid Cysts of Head and Neck Region - Case Series and Review of Literature
}

\author{
Quistes Epidermoides de Región Cabeza y Cuello - \\ Serie de Casos y Revisión de la Literatura
}

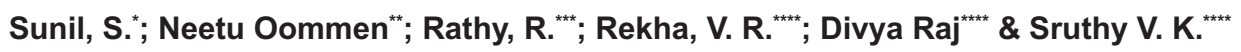

SUNIL, S.; OOMMEN, N.; RATHY, R.; REKHA, V. R.; RAJ, D. \& SRUTHY V. K. Epidermoid cysts of head and neck region - Case series and review of literature. Int. J. Odontostomat., 8(2):165-169, 2014.

ABSTRACT: Epidermoid and dermoid cysts are hamartomas localized on the neck, head, or trunk, usually visible at birth. In some instances, careful medical examination may help to find most epidermoid and dermoid cysts. Ambiguity about their exact pathogenesis exists and dysontogenetic, traumatic, and thyroglossal anomaly theories have been postulated. Histopathologically epidermoid cysts have a cystic capsule lined with thin stratified epithelium. Surgical excision though completes the treatment, complications have been reported. We report three cases of epidermoid cyst on the maxillofacial region.

KEY WORDS: cutaneous cyst, embryonic, keratin.

\section{INTRODUCTION}

Dermoid and epidermoid cysts are developmental cysts that occur in the head and neck with an incidence ranging from $1.6 \%$ to $6.9 \%$ (AlKhateeb et al., 2009). They represent less than $0.01 \%$ of all cysts of the oral cavity. An epidermal cyst is derived from epidermis, and is formed by cystic enclosure of epithelium within the dermis that becomes filled with keratin and lipid-rich debris. It occurs in young to middle-age adults. Men are affected more often than women in the ratio 3:1, with mean age 28 years (Al-Khateeb et al.; Smirniotopoulos \& Chiechi; Koellaer et al., 1999; Som, 1987; Park, 1995).

Histologically, they can be further classified as epidermoid (lined with simple squamous epithelium), dermoid (when skin adnexa are found in the cyst wall) or teratoid (when other tissues, such as muscle, cartilage and bone are present). We here report 3 cases of epidermoid cyst arising in the head and neck region.

\section{CASE REPORTS}

Case 1 . A4-year-old male child reported with a swelling on the right lateral frontozygomatic suture and eyelid, of size $1 \times 0.7 \mathrm{~cm}^{2}$. The swelling was soft, smooth, cystic, non-tender with limited mobility. A provisional diagnosis of dermoid/ epidermoid or sebaceous cyst was made (Fig. 1). Doppler ultrasound showed a well encapsulated ovoid cystic lesion of $10 \mathrm{~mm} \times 7 \mathrm{~mm}$ size.

The lesion was excised and sent for histopathologic examination. Macroscopic finding consisted of soft, cystic, grayish black, $1 \times 7 \times 0.5 \mathrm{~cm}^{3}$ tissue (Fig. 2). On sectioning a whitish cheesy material, probably keratin material was found (Fig. 3). Histopathologic examination of $\mathrm{H}-\mathrm{E}$ stained section showed fibrocellular cystic wall lined by thin layer of stratified epithelium (Fig. 4). A confirmatory diagnosis of Epidermoid cyst was made.

Case 2. A 22-year-old male reported with a swelling in the left cygomatic area of 3 months duration, increasing in size to present size of $1 \times 1 \mathrm{~cm}^{0}$. The swelling was

\footnotetext{
Professor, Department of Oral \& Maxillofacial Pathology, Azeezia College of Dental Sciences, Kerala, India.

** Senior Lecturer, Department of Oral \& Maxillofacial Pathology, Azeezia College of Dental Sciences, Kerala, India.

*** Professor \& Head, Department of Oral \& Maxillofacial Pathology, Azeezia College of Dental Sciences, Kerala, India.

${ }^{* * * *}$ PG trainee, Department of Oral \& Maxillofacial Pathology, Azeezia College of Dental Sciences, Kerala, India.
} 


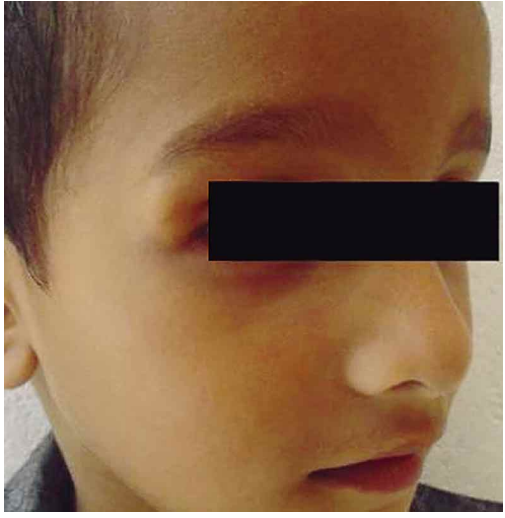

Fig. 1. Clinical photograph showing swelling around the right eyelid.

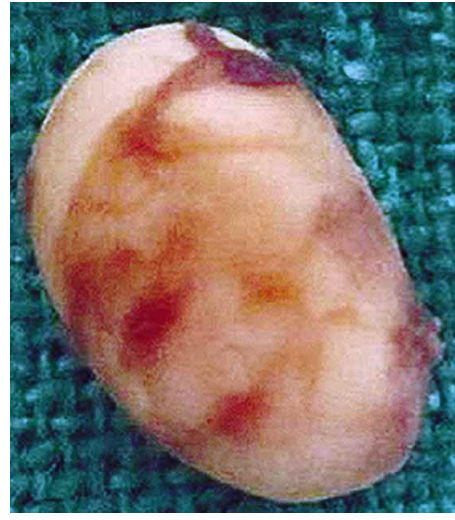

Fig. 2. Excised specimen of the lesion.

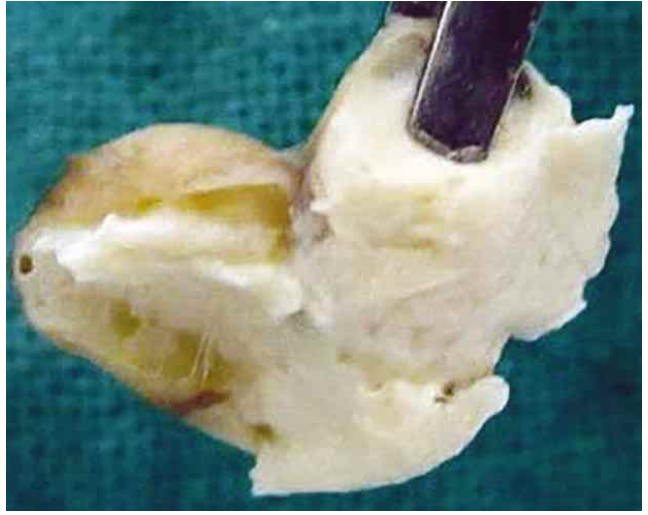

Fig. 3. Cut gross specimen revealed cheesy material.

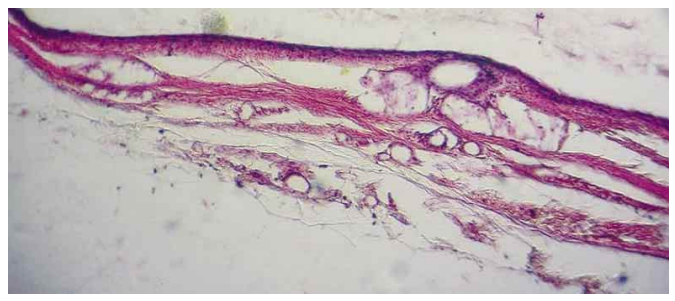

Fig. 4. H-E section showing cystic capsule lined by thin layer of stratified epithelium.

soft, cystic, non-tender with minimum mobility. A clinical diagnosis of dermoid/ epidermoid or sebaceous cyst was made. The lesion was excised and sent for histopathologic examination. Macroscopic finding consisted of soft, cystic, grayish black, $1.5 \times 1 \times 0.5 \mathrm{~cm}^{3}$ tissue. On sectioning

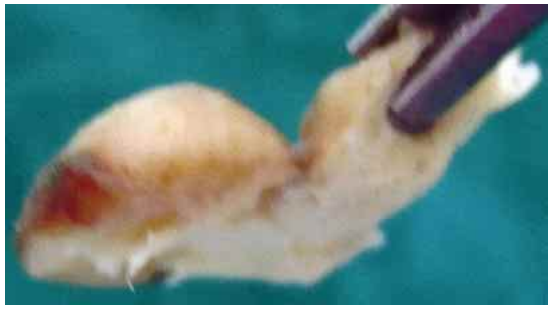

Fig. 5. Sectioned gross specimen.

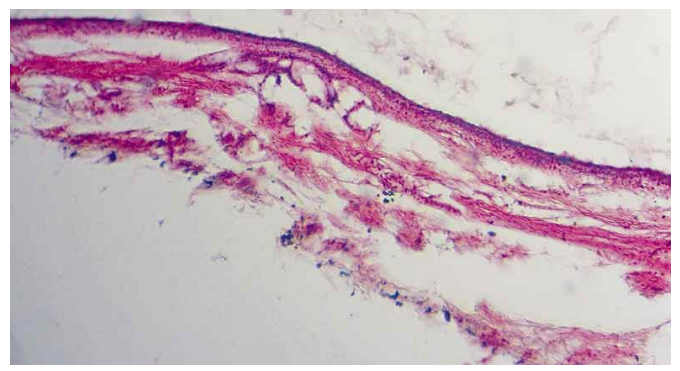

Fig. 6. H-E section showing fibrous cystic capsule and lining epithelium.

a whitish cheesy material, probably keratin material was found (Fig. 5). Histopathologic examination of $\mathrm{H}$-E stained section showed fibrocellular cystic wall lined by thin layer of stratified epithelium (Fig. 6). A confirmatory diagnosis of Epidermoid cyst was made.

Case 3. A 50-year-old male reported with a swelling on the right lateral border of tongue of 6 months duration, of size $2 \times 1 \mathrm{~cm}^{2}$. The swelling was soft, smooth and cystic (Fig. 7). A provisional diagnosis of dermoid/ epidermoid or sebaceous cyst was made. FNAC from the lesion showed keraninaceous material. The lesion was excised and send for histopathologic examination. Macroscopic finding consisted of soft, cystic, grayish black, $2 \times 1 \times 0.5 \mathrm{~cm} 3$ tissue. On sectioning a whitish cheesy material, probably keratin material was found. Histopathologic examination of $\mathrm{H}-\mathrm{E}$ stained section showed fibrocellular cystic wall lined by thin layer of stratified epithelium (Fig. 8). A confirmatory diagnosis of Epidermoid cyst was made.

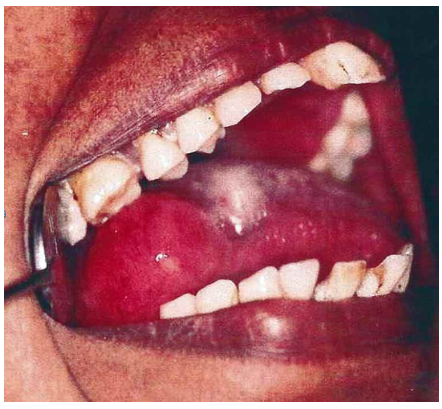

Fig. 7. Clinical photo showing swelling in the right lateral border of tongue.

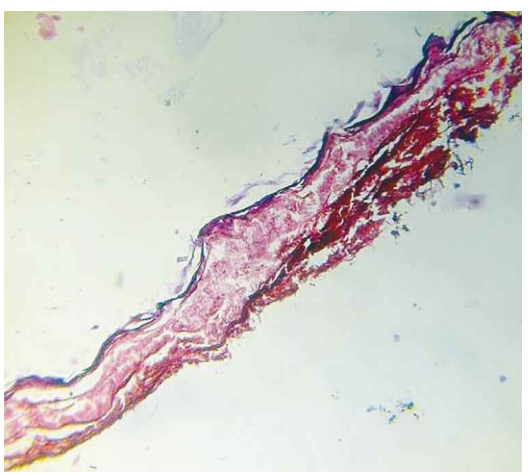

Fig. 8. H-E section showing fibrous cystic capsule and lining squamous epithelium. 


\section{DISCUSSION}

Epidermoid/Dermoid cysts are cystic malformations lined with squamous epithelium. In the head and neck region, the most common location is the lateral eyebrow. Out of all the dermoid cysts, which occur in the head and neck region, $11.5 \%$ are noted in the submental region (Smirniotopoulos \& Chiechi; Som). Epidermoid cysts, predominantly seen in areas where embryonic elements fuse together are benign lesions encountered throughout the body; most cases have been reported in ovaries and testicles (80\%). Head and neck account for about 1.6-7.0\%. Sublingual, submental and submandibular spaces are common localization in the floor of mouth. Rarely cases have been reported in the lips, oral mucosa, tongue, maxilla and mandible (Som; Park).

The head and neck sites affected most frequently with cutaneous cysts were the scalp (34\%), neck (18\%), periorbital area $(17 \%)$, cheeks \& lips (16\%), periauricular area $(9 \%)$, and nasal area (including forehead, 6\%) (Nicollas et al., 2000). Orbital dermoid cysts have been classified as either exophytic or endophytic, according to their site of attachment in relation to the orbital rims. The exophytic cysts grow externally and are discovered in childhood, whereas the endophytic ones are discovered later in life when they produce bone damage, with or without invasion of the adjacent structures (Nicollas et al.).

In the neck, these cysts usually present as midline slow growing masses, which gradually increase in size over the years due to the accumulation of cutaneous products. The lesions will be soft and mobile and the overlying skin is pinchable. The mass does not move with the protrusion of the tongue or the swallowing movements. The size of the cysts varies from few millimeters to $12 \mathrm{~cm}$ (Weedon \& Strutton, 2002; Ohta et al., 2012).

Several theories have been proposed to explain the development of dermoid cysts. They may result from entrapment of ectodermal tissue of the first and second branchial arches during fetal development. They could represent a variant form of the thyroglossal duct cyst. Finally, previous surgical or accidental events could lead to traumatic implantation of epithelial cells into deeper tissues. Epidermoid cysts are the result of implantation of epidermal elements in the dermis (Nicollas et al.; Weedon \& Strutton; Dive et al., 2012; Golden \& Zide, 2005).
It is usually solitary and connects with the surface by keratin- filled pores. Dermoid cysts lack any entry port and have a predilection for lines of embryonic fusion. Younger patients predominate for dermoid cyst presentation. Histologically, pilosebaceous structures may be noted within the wall of a dermoid cyst.

They express cytokeratins 1 and 10, constituents of the suprabasal layers of epidermis. The source of this epidermis is infundibulum of hair follicle, as the lining of these two structures are similar (Weedon \& Strutton; Ohta et al.).

Epidermoid cysts are slow growing and usually asymptomatic, but they may become inflamed or secondarily infected, resulting in pain and tenderness. Larger cyst of oral cavity may cause obstructive signs and symptoms like dyspnoea and dysphagia (Nicollas et al.; Weedon \& Strutton; Ohta et al.). Rarely malignancies, including basal cell carcinoma, Bowen disease, Squamous cell carcinoma, and mycosis fungoides have been reported in epidermoid cysts (Debaize et al., 2002). The cyst can occur at any age, most common in the third and fourth decades of life. Gardner syndrome is an exception, where the average age of incidence is 13 years.

Genital lesions can cause pain during urination or sexual activity. Plantar lesions may cause difficulty with walking or other activities (Silver \& Ho, 2003; Fitzpatrick, 2005). Oral lesions can cause difficulty in feeding, swallowing, or phonation (Weedon \& Strutton; Ohta et al.; Tolga et al., 2007; Yilmaz et al., 2006).

Clinically it may present as a round, firm, mobile flesh colored to yellow or whitish subcutaneous nodules of variable size. A central pore or punctum may be noticed. A thick cheesy material may be expressed. In a study from Indian population, $63 \%$ of the cysts showed melanin pigmentation (Dive et al.).

Suggested etiology includes sequestration of epidermal rests during embryonical life, occlusion of pilosebaceous unit and traumatic surgical implantation of epithelial elements. HPV infection and eccrine duct occlusion may be additional factors in the development of palmoplantar epidermoid cysts (Nicollas et al.; Weedon \& Strutton). 
The lesions to be considered in the differential diagnosis include branchial cleft cysts, calcinosis cutis, dermoid cyst, Gardner's syndrome, lipoma, milia, Nevoid basal cell carcinoma, Pachyonychia congenita and pilar cyst (Weedon \& Strutton; Golden \& Zide ).

The origin of epidermoid/dermoid cyst in the oral cavity is controversial. Implantation keratinizing epidermoid cysts may occur in other parts of mouth due to trauma. An implantation epidermoid cyst in the mandibular condyle within two years following a surgical treatment in the site has been reported (Abrams et al., 1997).

Histopathologically, dermoid and epidermoid cysts are lined by keratinized epidermis with occasional areas of pseudostratified ciliated columnar epithelium, but cysts of floor of mouth may be predominantly have secretory epithelium of salivary duct origin. Dermoid cysts in addition have one or more dermal appendages like hair follicle, sweat glands or sebaceous glands in the connective tissue wall. Lumen is usually filled with keratin (Samper, 2000; Scolozzi et al., 2005).

Intracranial, intraspinal, or intra-abdominal dermoid cysts may be suspected after specific or nonspecific neurologic or gynecologic symptoms occur. In these instances, imaging studies (Radiography, CT scanning, and MRI) may help in distinguishing dermoid cysts from other tumors or organ malformations. A congenital intracranial frontotemporal dermoid cyst may be first evident as a cutaneous fistula, although intracranial extension and cutaneous sinus tract formation are rarely seen with these dermoid cysts (Scolozzi et al.).

Unilateral upper eyelid swelling may be the first sign, with imaging studies demonstrating a soft tissue orbital epidermoid / dermoid cyst arising from the lacrimal gland. An eyelid epidermoid / dermoid cyst attached to a tarsus may be evident as a firmly adherent nontender upper-eyelid nodule (Samper). Dermoid tumors in the medial canthal area may present as masses adherent to the lacrimal canaliculi (Golden \& Zide).

Treatment of epidermoid/dermoid cysts of the soft tissues is surgical excision (Nicollas et al.; Golden \& Zide).

Complications. Several possible complications of spontaneous or post traumatic rupture and surgical procedures have been described. In patients with a ruptured spinal dermoid cyst, fatty droplets can disseminate in the cerebrospinal fluid or in a dilated central canal of the spinal cord. In other patients, subarachnoid and ventricular fat dissemination can occur after the cerebellopontine angle dermoid cyst is resected. Spinal subdural abscesses are a possible complication because of the bacterial infection of spinal dermoid cysts in a dermal sinus tract.

A ruptured intracranial dermoid cyst be an incidental finding on an MRI performed for other purposes or because of a persistent headache (Scolozzi et al.). Deglutition and speech problems may occur in intralingual dermoid cysts (Tolga et al.; Yilmaz et al.).

Malignant transformation is an unusual complication that may occur in patients with long-standing dermoid cysts (Debaize et al.). Carcinomatous transformation to a squamous cell carcinoma is described in sublingual and intra-abdominal dermoid cysts, most often dermoid cysts of the ovary. Metastatic malignant melanomas arising from dermoid cysts have been reported.

SUNIL, S.; OOMMEN, N.; RATHY, R.; REKHA, V. R.; RAJ, D. \& SRUTHY V. K. Quistes Epidermoides de región cabeza y cuello - Serie de casos y revisión de la literatura. Int. J. Odontostomat., 8(2):165-169, 2014.

RESUMEN: Los quistes epidermoides y dermoides son hamartomas localizados en el cuello, la cabeza o el tronco, por lo general visibles al nacer. En algunos casos, el examen médico cuidadoso puede ayudar a encontrar quistes epidermoides y dermoides. Existe cierta ambigüedad acerca de su patogenia exacta, postulando teorías disontogenéticas, traumáticas y anomalías del conducto tirogloso. Los quistes epidermoides histopatológicamente tienen una cápsula quística revestida con epitelio estratificado delgado. Aunque la escisión quirúrgica completa es su tratamiento, se han reportado complicaciones. Presentamos tres casos de quiste epidermoides en la región maxilofacial.

PALABRAS CLAVE: quiste cutáneo, embrionario, queratina. 


\section{REFERENCES}

Abrams, M. B.; Andrews, J. E. \& Laskin, D. M. Epidermoid (implantation) cyst after temporomandibular joint surgery. J. Oral Surg., 35(7):587-9, 1977.

Al-Khateeb, T. H.; Al-Masri, N. M. \& Al-Zoubi, F. Cutaneous cysts of the head and neck. J. Oral Maxillofac. Surg., 67(1):52-7, 2009.

Debaize, S.; Gebhart, M.; Fourrez, T.; Rahier, I. \& Baillon, J. M. Squamous cell carcinoma arising in a giant epidermal cyst: a case report. Acta Chir. Belg., 102(3):196-8, 2002.

Dive, A. M.; Khandekar, S.; Moharil, R. \& Deshmukh, $\mathrm{S}$. Epidermoid cyst of the outer ear: A case report and review of literature. Indian J. Otol., 18(1):34-7, 2012.

Fitzpatrick, T. B. Fitzpatrick's Color Atlas and Synopsis of Clinical Dermatology. $5^{\text {th }}$ ed. New York, McGrawHill, 2005.

Golden, B. A. \& Zide, M. F. Cutaneous cysts of the head and neck. J. Oral Maxillofac. Surg., 63(11):1613-9, 2005.

Koeller, K. K.; Alamo, L.; Adair, C. F. \& Smirniotopoulos, J. G. Congenital cystic masses of the neck: radiologic-pathologic correlation. Radiographics, 19(1):121-46, 1999.

Nicollas, R.; Guelfucci, B.; Roman, S. \& Triglia, J. M. Congenital cysts and fistulas of the neck. Int. J. Pediatr. Otorhinolaryngol., 55(2):117-24, 2000.

Ohta, N.; Watanabe, T.; Ito, T.; Kubota, T.; Suzuki, Y.; Ishida, A.; Kakehata, S. \& Aoyagi, M. A case of sublingual dermoid cyst: extending the limits of the oral approach. Case Rep. Otolaryngol., 2012:634949, 2012.

Park, Y. W. Evaluation of neck masses in children. Am. Fam. Physician, 51(8):1904-12, 1995.

Samper, A.; Ruiz de Erenchun, R.; Yeste, L. \& Bazan, A. Dermoid cyst on the auriculotemporal area. Plast. Reconstr. Surg., 106(4):947-8, 2000.
Scolozzi, P.; Lombardi, T. \& Jaques, B. Congenital intracranial frontotemporal dermoid cyst presenting as a cutaneous fistula. Head Neck, 27(5):429-32, 2005.

Silver, S. \& Ho, V. Epidermal and appendageal tumors. In: Freedberg, I.; Eisen, A. \& Wolff, K. (Eds.). Fitzpatrick's Dermatology in General Medicine. $6^{\text {th }}$ ed. New York, McGraw-Hill, 2003.

Smirniotopoulos, J. G. \& Chiechi, M. V. Teratomas, dermoids, and epidermoids of the head and neck. Radiographics, 15(6):1437-55, 1995.

Som, P. Cystic lesions of the neck. Postgrad. Radiol., 7:211-36, 1987.

Tolga, K.; Murat, K.; Enver, V.; Elif, S. \& Ozlem, S. Sublingual epidermoid cyst: A case report. J. Med. Case Reports, 1:87, 2007.

Weedon, D. \& Strutton, G. Cysts and Sinuses in Skin Pathology. $2^{\text {nd }}$ ed. Edinburgh, Churchill Livingstone, 2002. p.246.

Yilmaz, I.; Yilmazer, C.; Yavuz, H.; Bal, N. \& Ozluoglu, L. N. Giant sublingual epidermoid cyst: a report of two cases. J. Laryngol. Otol., 120(3):E19, 2006.

Correspondence to:

Dr. S. Sunil

Sougandhikam, T.C. 1/858

Jainagar, Medical College

Trivandrum

Kerala, 695011

INDIA

Email: drsunil74@rediffmail.com

Received: 09-01-2014

Accepted: 26-04-2014 